\title{
TOTAL MERCURY CONTENT OF SKIN TONING CREAMS AND THE POTENTIAL RISK TO THE HEALTH OF WOMEN IN GHANA
}

\author{
R. B. Voegborlo, S. E. Agorku, B. Buabeng-Acheampong and E. Zogli \\ Department of Chemistry, \\ Kwame Nkrumah University of Science \& Technology, \\ Kumasi, Ghana
}

\begin{abstract}
The use of mercury containing skin toning creams is becoming increasingly popular among darkskinned women. The prolonged use of them over the years may cause serious health effects. In the study sixty nine (69) samples of skin toning creams were analysed for total mercury by cold vapour atomic absorption spectrophotometry using an automatic mercury analyzer. The concentration of mercury in the creams ranged from below 0.001 to $0.311 \mathrm{\mu g}^{-1}$. All the creams sampled had concentrations less than the US Food and Drug Administration's acceptable limit of $1 \mathrm{\mu g} \mathrm{g}^{-1}$. The low concentrations of mercury detected in the cream samples analysed therefore do not pose any potential mercury related health risk to the population particularly women
\end{abstract}

Keywords: mercury, skin toning cream, women, health

\section{INTRODUCTION}

Mercury is a very toxic element but its use has been found in many areas including use for religious, cultural and ritualistic purposes. Mercury has also been used in some traditional medicines (such as certain Traditional Asian remedies), as a preservative in some vaccines and other pharmaceuticals and in skin-lightening (toning) creams and soaps. The application of mercurial preparations to the skin has been practiced for centuries (Cole et al., 1930; Turk and Baker, 1968). It is known from history that mercury was used in ointments by the Greeks and the Romans also used it for cosmetics (Silberberg, 1995). Mercurycontaining cosmetic preparations have been represented for many years as skin-bleaching agents or as preparations to remove or prevent freckles and/ or brown spots (Al-Saleh and Al-Doush, 1997). Preparations intended for such use are regarded as drugs as well as cosmetics. In addition to such use as skin-bleaching agents, mercury compounds have also been widely used as preservatives in hand and body creams and lotions; hair shampoos, hair sets and rinses, hair straighteners, hair colouring, and other preparations. 
The toning creams containing mercury in the form of inorganic mercury are mainly used by dark-skinned people mostly in developing countries notably in Africa and Asia to lighten their skin tone. This has been reported to be probably due to the inhibition of the production of the skin pigment melanin (Marzulli and Brown, 1972; Barr et al., 1973; Bourgeois et al., 1986; Katzung, 1995).

Cosmetic preparations containing mercury compounds are often applied with regularity and frequency for prolonged periods. Such chronic use of mercury-containing skin-bleaching preparations has resulted in the accumulation of mercury in the body after absorption through the skin; especially in the kidney where it mainly accumulates in the tubular region, giving rise to the occurrence of severe reactions (Marzulli and Brown, 1972; Barr et al., 1973; Berlin, 1979; Bourgeois et al., 1986). Mercury from the products enters the body by penetrating the skin and also via inhalation (WHO, 1991; Glahder et al., 1999; Al-Saleh et al., 2004; Al-Saleh and Shinwari, 2004). A recent study reported that mercury was readily absorbed through the skin of both albino and pigmented mice as evidenced with its accumulation in the brain, kidney and liver tissues (Al-Saleh et al., 2004). The most frequently observed effects of inorganic mercury on humans are connected with the central nervous system, the kidneys and the skin (WHO, 1991). Nephrotoxic effects have been attributed to the topical application of inorganic mercury salts (Millar, 1916; Silverberg et al., 1967; Barr et al., 1973; Kibuhamusohe et al., 1974; Lyons et al., 1975; Berlin, 1979; Jeddeloh et al., 1985). Studies have also indicated that permanent kidney dysfunction can be induced by exposure to nephrotoxic chemicals during prenatal periods (Neubert et al., 1985; Lauwerys et al., 1987). Exposure of placental cells to mercury causes accumulation of the metal in the placental membrane and lowers the membrane fluidity, which may affect membrane function and cause damage to the developing fetus (Boadi et al., 1992). It has been demonstrated that low mercury levels in mothers during pregnancy affect the ability of their children to solve mental problems (Grandjean et al., 1999).

Studies have shown that women using soap and cream containing mercury attain mercury concentrations in their urine from 0.03 to $0.15 \mathrm{mg}$ per litre. At these concentrations, there is a major risk of negative effects on their central nervous system and kidneys, since such effects have been demonstrated at concentrations from 0.02 to $0.5 \mathrm{mg}$ per litre. Women with an average urine mercury concentration of $0.15 \mathrm{mg}$ per litre have been reported to have developed kidney diseases (Glahder et al., 1999). A clinical investigation of Kenyan women with damaged kidneys revealed that they suffered from a higher incidence of nephritic syndrome, which was attributed to the use of creams containing mercury (Barr et al., 1973). There is, therefore the justification for banning mercury-containing soaps and creams, which are manufactured and sold under the presumption of being antiseptic, although the real purpose is to bleach human skin and hair. The distribution of mercury-containing soaps and creams has subsequently been banned in the European Economic Community, in North America, and in many African States as well. Mercury-containing products are, however, manufactured in several European countries and these are exported and sold illegally in the Third World Countries including Ghana. English Community Health Authorities have identified several brands of skin-lightening creams containing ammoniated mercury between 1 and 5\% (Marzulli and Brown, 1972) and in some cases between 5 and 10\% (Barr et al., 1973). It has also been shown that even under conditions of good manufacturing practice; trace amounts of mercury in cosmetics are unavoidable. Therefore, the United States Food and Drug Administration (US FDA) in 1992 established the maximum acceptable level of mercury in cosmetics to be $1 \mu \mathrm{g} \mathrm{g}^{-1}$.

In Ghana, concerns have been expressed about the widespread use of skin lightening creams. This is particularly worrying in the light that the number 
of people especially women of all ages involved in the use of these creams seems to be on the increase (Dorkenoo, 1998). The wide availability of the numerous brands of skin-toning creams on the Ghanaian market that are mostly imported has necessitated this study to investigate whether high levels of mercury are found in the skin toning creams on sale in the market.

\section{MATERIALS AND METHODS Apparatus}

All glassware used were soaked in detergent solution overnight; rinsed and soaked in $10 \%(\mathrm{v} / \mathrm{v})$ $\mathrm{HNO}_{3}$ overnight. They were rinsed with distilled water followed by $0.5 \%(\mathrm{w} / \mathrm{v}) \mathrm{KMnO}_{4}$ and finally rinsed with distilled water before use.

Automatic Mercury Analyzer Model HG-5000 (Sanso Seisakusho Co., Ltd, Japan), equipped with mercury lamp operated at a wavelength of $253.7 \mathrm{~nm}$ was used for the determinations. The signals were obtained on a Yokogawa Model 3021 strip chart recorder.

Digestion apparatus was thick walled long neck $50 \mathrm{ml}$ volumetric flasks and a hot plate with a temperature range of $150-350^{\circ} \mathrm{C}$ (Clifton, U.K.)

\section{Reagents}

All reagents used were of analytical reagent grade (BDH Chemicals Ltd, Poole, England) unless otherwise stated. Double distilled water was used for the preparation of all solutions.

Mercury stock standard solution (1000 $\mathrm{mg} \mathrm{L}^{-1}$ ) was prepared by dissolving $0.0677 \mathrm{~g}$ of $\mathrm{HgCl}_{2}$ in the acid mixture $\mathrm{HNO}_{3}: \mathrm{H}_{2} \mathrm{SO}_{4}: \mathrm{HClO}_{3}(2: 10: 2)$ in a $50 \mathrm{ml}$ digestion flask with heating on a hot plate at a temperature of $200^{\circ} \mathrm{C}$ for $30 \mathrm{~min}$. The clear solution was then diluted to $50 \mathrm{ml}$ with water. Blank solutions were also prepared alongside and bulked together for use as a diluent. The working solutions were freshly prepared by diluting an appropriate aliquot of the stock solution through intermediate solutions using blank solution. Stannous chloride solution $(10 \% \mathrm{v} / \mathrm{v})$ was prepared by dissolving $10 \mathrm{~g}$ of the salt in $100 \mathrm{ml} 1 \mathrm{M} \mathrm{HCl}$. The solution was aerated with nitrogen gas at $50 \mathrm{ml}$ $\min ^{-1}$ for $30 \mathrm{~min}$ to expel any elemental mercury from it.

\section{Sampling and Digestion Procedure}

Sixty nine skin-lightening cream samples were obtained from local markets in the city of Accra and Kumasi. The samples were digested for total mercury determination by a modified version of an open flask procedure developed at the National Institute for Minamata Disease (NIMD) in Japan (Akagi and Nishimura, 1991). Approximately 0.5 $\mathrm{g}$ of each cream sample was weighed accurately into a $50 \mathrm{ml}$ volumetric digestion flask and $1 \mathrm{ml}$ of deionised water was added. A $5 \mathrm{ml}$ mixture of nitric acid and perchloric acid (1:1) was then added and swirled. The solution was heated at $200^{\circ} \mathrm{C}$ for 30 minutes to obtain a clear solution. The solution was allowed to cool and made up to volume with double distilled water. A blank and standard solution digests using 25, 50 and $100 \mu \mathrm{l}$ of $1 \mu \mathrm{g} \mathrm{ml}^{-1}$ standard $\mathrm{Hg}$ solution were subjected to the same treatment. The concentrations of the standard solution digests obtained were $0.5,1$ and $2 \mathrm{ng} \mathrm{ml}^{-1}$.

The accuracy and precision of the method used were determined by analyses of procedural blanks and calibration standards, triplicate sub-samples, spiked sub-samples and certified reference materials from the National Research Council of Canada.

\section{Determination of Mercury}

Determination of mercury in all the digests was carried out by cold vapour atomic absorption spectrophotometry using an Automatic Mercury Analyzer Model HG-5000 (Sanso Seisakusho Co., Ltd, Japan) developed at National Institute for Minamata Disease (NIMD) in Japan. The analyzer consists of an air circulation pump, a reaction vessel, $\mathrm{SnCl}_{2}$ dispenser, an acidic gas trap and a fourway stop-cock with tygon tubes to which is attached a ball valve. The operations of the ball valve and the air circulation pump are controlled by a microprocessor. A schematic diagram of the 
system is shown in Fig 1. During the determination, a known volume of the sample solution normally $5 \mathrm{ml}$ is introduced into the reaction vessel using a micropipette $(1-5 \mathrm{ml})$. The reaction vessel is immediately stoppered tightly and $0.5 \mathrm{ml}$ of 10 $\%(\mathrm{w} / \mathrm{v}) \mathrm{SnCl}_{2} .2 \mathrm{H}_{2} \mathrm{O}$ in $1 \mathrm{M} \mathrm{HCl}$ is added from a dispenser for the reduction reaction. During this time, air is circulated through the four-way stopcock to allow the mercury vapour to come to equilibrium and the acidic gases produced by the reaction also swept into the sodium hydroxide solution. After 30 seconds the four-way stopcock is rotated through $90^{\circ}$ and the mercury vapour is swept into the absorption cell. Response was recorded on the strip chart recorder as a very sharp peak. Peak heights were used for computations.

\section{RESULTS AND DISCUSSION}

The method described in this paper for the determination of mercury in cream provides a rapid, sensitive and accurate procedure that can be used for routine analysis of skin lightening creams. It facilitates the relatively rapid $(30 \mathrm{~min})$ wet oxidation of samples $(0.5-1 \mathrm{~g})$.

Precision and accuracy of the procedure were evaluated by repeated analyses of samples and certified reference material (Dogfish muscle) from the National Research Council (NRC) of Canada and by recovery studies. The validity of the method has been proved by the agreement between the measured $\left(4.60-4.76 \mu \mathrm{g} \mathrm{g}^{-1}\right)$ and certified $\left(4.15-4.79 \mu \mathrm{g} \mathrm{g}^{-1}\right)$ concentrations in Dogfish muscle (DORM-2) Certified Reference Material. The results from the analysis were all within the 95\% confidence limit. Recovery studies were performed by spiking sub-samples of two skinlightening creams known to have non detectable levels of mercury with suitable aliquots $(25 \mu \mathrm{l}, 50$ $\mu \mathrm{l})$ of $1 \mu \mathrm{g} \mathrm{ml}{ }^{-1}$ standard mercury solution. The spiked cream samples were then digested using

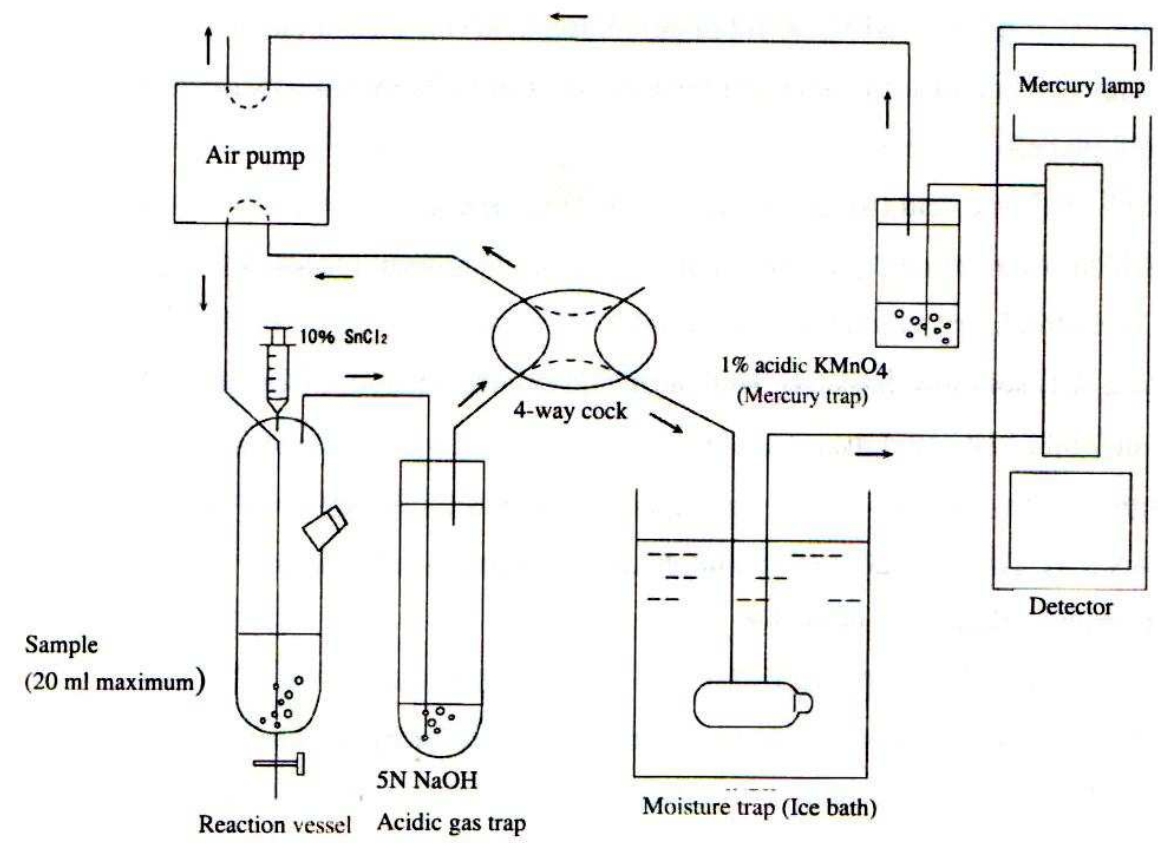

Fig 1. Apparatus for Mercury Determination by Cold Vapour Atomic Absorption Spectrophotometry (CVAAS) 
the same procedure and mercury determined in the digests. Good recoveries (94-98\%) of the spiked samples demonstrated the accuracy of the method used.

Mercury levels were determined in a total of sixty -nine (69) samples from different countries. The results obtained are presented in Table 1. Mercury concentration ranged from less than 0.001 to $0.311 \mu \mathrm{g} \mathrm{g}^{-1}$ with most of them below $0.1 \mu \mathrm{g} \mathrm{g}^{-1}$. All the samples had concentration of mercury below the $1.0 \mu \mathrm{g} \mathrm{g}^{-1}$ limit recommended by the United States Food and Drug Administration (US FDA). Out of the 69 samples analysed 11 samples equivalent to about $16 \%$ had levels less than $0.001 \mu \mathrm{g} \mathrm{g}^{-1}$. The concentration of mercury in skin toning creams has been the subject of study in recent years and the mercury content of creams has variously been reported (WHO, 1991; AlSaleh and Al-Doush, 1997; Kahatano et al., 1998; Glahder, 1999).

Table 1: Mercury concentrations in skin lightening creams

\begin{tabular}{|c|c|c|c|}
\hline Product Name & $\begin{array}{c}\text { Mercury } \\
\left(\mu \mathrm{g} \mathrm{g}^{-1}\right)\end{array}$ & Country of Origin & Colour \\
\hline Aleo Whitening Milk & 0.013 & China & White \\
\hline Aquamarine Revlon & $<0.001$ & Unknown & Pale brown \\
\hline Bio Claire & $<0.001$ & Cote d'Ivoire & White \\
\hline Body Clair Cream & 0.031 & Cote d'Ivoire & White \\
\hline Body Clear (Extra strength) & $<0.001$ & France & White \\
\hline Body Clear lightening body cream & 0.003 & Cote d'Ivoire & White \\
\hline Cherie Claire & 0.008 & Cote d'Ivoire & White \\
\hline Clear \& Smooth Cream (White moon) & 0.001 & Italy & White \\
\hline Clear Essence & 0.076 & Unknown & White \\
\hline Clear Liss & 0.013 & Cote d'Ivoire & White \\
\hline Clear Plus & 0.010 & Cote d'Ivoire & White \\
\hline Clear Touch No. 1 & 0.043 & Germany & White \\
\hline Clear-N-Smooth & 0.009 & USA & White \\
\hline Cream Cocoa Butter & 0.079 & Unknown & Yellow \\
\hline Crusader Ultra Brand & 0.002 & England & Light pink \\
\hline Dawny & 0.002 & Cote d'Ivoire & White \\
\hline Dermo-Gel Plus & 0.009 & Switzerland & White \\
\hline Dermovate Cream & 0.002 & Saudi Arabia & White \\
\hline Esapharma Movate Cream & 0.014 & Italy & White \\
\hline Evita Skin Beautifying Milk & 0.002 & Britain & Pale brown \\
\hline Extra-Claire & 0.008 & USA & White \\
\hline Fair \& Beautiful (Maxi-Tone) & $<0.001$ & Switzerland & Pale brown \\
\hline Faire Age & 0.008 & Unknown & White \\
\hline Fashion Fair Cream & 0.045 & Italy & White \\
\hline Fennel & 0.016 & USA & White \\
\hline First Lady Softening Cream & 0.002 & Cote d'Ivoire & Light pink \\
\hline Forever Claire (Maxitone-skin tone) & $<0.001$ & Ghana & Yellow \\
\hline $\mathrm{G} \& \mathrm{G}$ & 0.022 & Cote d'Ivoire & White \\
\hline Habiba & 0.002 & Cote d'Ivoire & Light brown \\
\hline
\end{tabular}

92 Journal of Science and Technology, Vol. 28, No. 1, April 2008 


\begin{tabular}{|c|c|c|c|}
\hline Product Name & $\begin{array}{c}\text { Mercury } \\
\left(\mu \mathrm{g} \mathrm{g}^{-1}\right)\end{array}$ & Country of Origin & Colour \\
\hline Hyprogel & 0.002 & Germany & Light pink \\
\hline IKB (Skin litener cream) & 0.001 & England & White \\
\hline Immediat Claire & 0.029 & Cote d'Ivoire & Yellow \\
\hline Lemonvate ${ }^{\circledR}$ Cream & 0.017 & Italy & Yellow \\
\hline Marie Claire & 0.020 & Cote d'Ivoire & Pink \\
\hline Maxi tone lightening lotion & 0.046 & USA & White \\
\hline Maxi-Light & 0.020 & Cote d'Ivoire & White \\
\hline Nea-vate (White Cream Plus) & 0.057 & Italy & White \\
\hline New Age Avance Formula & 0.002 & Italy & White \\
\hline New Age Skin Beautifying Milk & $<0.001$ & USA & Pale brown \\
\hline Niuma Lightening Cream & 0.053 & Spain & White \\
\hline Nivea cream & $<0.001$ & England & Light brown \\
\hline Nymph & 0.021 & France & White \\
\hline Olay Quench & 0.023 & Unknown & White \\
\hline P \& C Lightening Cream & $<0.001$ & Unknown & Off-white \\
\hline Palmers Skin Success (Eventone Fade) & $<0.001$ & USA & Pale brown \\
\hline Paula Complexion Milk & 0.211 & USA & Light brown \\
\hline Peau Claire & 0.083 & Cote d'Ivoire & White \\
\hline Pharmaderm & $<0.001$ & Cote d'Ivoire & White \\
\hline Pro-one Gel & 0.311 & Italy & White \\
\hline Reneu Beautifying Skin Milk & 0.002 & USA & White \\
\hline Sivoclair & 0.059 & Cote d'Ivoire & Yellow \\
\hline Sivoderm & 0.002 & Cote d'Ivoire & Cream \\
\hline Skimbo Gel & 0.050 & Italy & White \\
\hline Skin Beautifying Milk & 0.032 & USA & White \\
\hline Skin Beauty (Complexion Lotion) & 0.016 & France & Off-white \\
\hline Skin Light & 0.108 & Cote d'Ivoire & White \\
\hline Skin Success Cream & 0.029 & Italy & White \\
\hline Skin Success Gel Plus & 0.106 & Italy & White \\
\hline Skin Success Palmer & 0.116 & USA & Pink \\
\hline Skin White & 0.119 & France & White \\
\hline Star cream & 0.012 & Italy & White \\
\hline Tempovate Cream & 0.004 & Germany & White \\
\hline Temprosone cream & 0.002 & Germany & White \\
\hline Tendrina Complexion Cream & 0.092 & Cote d'Ivoire & Yellow \\
\hline Tenovate Gel & 0.042 & Italy & White \\
\hline Topsone Gel & 0.016 & Italy & White \\
\hline Touche Claire Extra (O'tentika) & 0.002 & Switzerland & White \\
\hline Tura Skin Toning Cream & $<0.001$ & England & Light pink \\
\hline Turci & 0.025 & Unknown & Brown \\
\hline
\end{tabular}


In a similar study on creams obtained in the Saudi Arabian market, mainly originating from Asia and the Middle East using inductively coupledplasma spectrometry (ICP), mean mercury concentration was $376.58 \mathrm{ppm}$ with a range from 0 to $5650 \mathrm{ppm}$. The highest mercury concentrations were found in 17 skin-lightening cream samples ranging from 1.18 to 5650 (Al-Saleh and AlDoush, 1997) which were all excessively higher than the US FDA permissible limit. This is expected to pose a potential health hazard particularly for women using such creams. Though effects of mercury poisoning on the skin itself have not been reported in relation to the use of mercury containing soap and cream, other toxic effects have been reported. Marzulli and Brown (1972) found that the use of skin lightening creams containing inorganic mercury salts result in substantial absorption and accumulation in the body. Repeated application of these skin toning creams could cause cumulative effects of prolonged low level mercury exposure, which could lead to a nephritic syndrome (Giunta et al., 1983; Rosenman et al., 1986; Enwonwu, 1987). Mercury can also be transferred from the mother to the fetus during pregnancy (Kuhnert et al., 1981; Lauwerys et al., 1987). It has been reported that the topical application of $17.5 \%$ mercuric ammonium chloride resulted in facial mercury pigmentation and possible neuropsychiatric toxicity in a 42 year old woman (Dyall-Smith and Scurry, 1990). Mercury from soap and cream has been reported to be readily absorbed through the skin and via inhalation (WHO, 1991; Al-Saleh et al., 2004; Al-Saleh and Shinwari, 2004) and this has been suggested in some studies. An average of $0.1 \mathrm{mg}$ mercury per litre of urine was found in a group of 60 women from Kenya who had used cream containing 5 to $10 \%$ ammoniated mercury; 26 of these women who had an average of $0.15 \mathrm{mg}$ per litre had developed the nephritic syndrome (renal diseases). In another study carried out in Tanzania some women who were not active in artisanal gold mining had up to $0.1 \mathrm{mg}$ mercury per litre of urine, and it was concluded that the mercury was derived from soap and cream containing mercury (Kahatano et al., 1998).

In view of these negative effects from the topical application of skin lightening creams to which mercury has been added as an active ingredient, the low levels of mercury obtained in the creams analysed from Ghana do not seem to pose any potential health hazard to particularly women in Ghana. Most of the creams analysed in this study originate mainly from USA, Cote d'Ivoire and Europe where it is possible that manufacturing regulations concerning skin lightening creams as far as mercury is concerned is being adhered to. On the other hand most of the creams analysed by Al-Saleh et al (1997) originated from Asia and Middle East except five samples from Europe in which mercury was less than $0.001 \mu \mathrm{g} \mathrm{g}^{-1}$. Coincidentally a common sample, Palmer's Skin Success (Fade cream) was analysed in our study and that of Al-Saleh et al (1997) and non detectable levels were obtained in both cases. It is possible therefore that the high levels of mercury in creams that originate from certain parts of the world can be attributed to the unavailability of regulations and laws against the manufacture, export, import and sale of mercury containing creams. The wide range of skin lightening creams on the Ghanaian market as well as their wide use by some women in an attempt to convert their dark skin to fair skin indicate that the bleaching effect from the use of the creams may be due to other active ingredients other than mercury added to the creams. Though the scope of this study does not include the other bleaching ingredients in skin lightening creams it can be concluded that there is no potential mercury related health risk from the use of the creams studied.

\section{ACKNOWLEDGMENT}

The technical assistance of the staff of National Institute for Minamata Disease (NIMD) to one of the authors (RBV) during his visit to the institute is highly acknowledged. 


\section{REFERENCES}

Akagi, H., and Nishimura H. (1991). Speciation of Mercury in the Environment. In: T. Suzuki, N. Imura \& T. W. Clarkson, (Eds), Advances in Mercury Toxicology, Plenum Press, USA, 53 - 76

Al-Saleh, I. and Al-Doush, I. (1997). Mercury Content in Skin Lightening creams and potential hazards to the health of Saudi Women. J Toxicol Environ Hlth 51: 123-130.

Al-Saleh, I. and Shinwari, N. (2004). Urinary mercury levels in females: Influence of skin lightening creams and dental amalgam fillings. Biometals 10: 315-323.

Al-Saleh, I., Shinwari, N., El-Doush, I., Billedo, G., Al-Amodi, M and Khogali, F. (2004). Comparison of mercury levels in various tissues of albino and pigmented mice treated with two different brands of mercury skin lightening creams. Biometals 17: 167-175

Barr, R. D., Woodger, B. M. and Rees, P. H. (1973). Levels of mercury in urine correlated with the use of skin lightening creams. Am J Clin Pathol 59: 36-40.

Berlin, M. (1979). Mercury. In: Friberg, F, Nordberg, G. F. and Vouk, V. L. (Editors) Handbook on the toxicology of metals, pp 503-530. Amsterdam:Elsevier/North-Holland.

Boadi, W. Y., Urbach, J., Brandes, J. M. and Yannai, S (1992). In vitro exposure to mercury and cadmium alters term human placental membrane fluidity. Toxicol Appl Pharmacol 116: 17-23.

Bourgeois, M., Dooms-Goossens, A., Knockaert, D., Sprenger, D, Van Boven, M. and Van Tittelboom, T. (1986). Mercury intoxication after topical application of a metallic mercury ointment. Dermatologica 172: 48-51

Cole, H. N., Schreiber, N. and Sollman, T. (1930). Mercurial ointment in the treatment of syphilis. Arch Dermatol 21: 372-393.
Dorkenoo T. (1998). Skin Bleaching. "The Pandemic is Here" Weekly Spectator, vol. 572 p2

Dyall-Smith, D. J. and Scurry, J. P. (1990). Mercury pigmentation and mercury levels from the use of cosmetic cream. Med J Aust 153: 409-415.

Enwonwu, C. O. (1987). Potential health hazard of the use of mercury in dentistry: Critical review of the literature. Environ Res 42: 257274.

Giunta, F., Dilandro, D. and Chiarmda, M. (1983). Severe acute poisoning from the ingestion of a permanent wave solution of mercuric chloride. Human Toxicol 2: 243-246.

Glahder, C. M., Appel, P. W. U. and Asmund, G. (1999). Mercury in Soap in Tanzania. NERI Technical Report No. 306 National Environmental Research Institute, Denmark. pp. 19.

Grandjean, P., White, R. F., Nielsen, A., Clearly, D. and de Oliveira Santos, E. C. (1999). Methylmercury Neurotoxicity in Amazonian Children Downstream from Gold Mining. Environmental Health Perspectives 107: 711.

Jeddeloh, R., Lake, K. D. and Brown, D. C. (1985). Ammoniated mercury membranous nephropathy. Minn Med 68: 591-592.

Kahatano, J. M. J., Mnali, S. R. and Akagi, H. (1998). A study of Mercury Levels in Fish and Humans in Mwakitolyo Mine and Mwanza Town in the Lake Victoria Goldfields, Tanzania, In: Landner, L. (Editor) Small scale Mining in African Countries. Proceedings of an International Conference, $29^{\text {th }}$ September to $1^{\text {st }}$ October, 1997, Dar es Salaam, Tanzania.

Katzung, B. G. (1995). Basic and Clinical Pharmacology, $6^{\text {th }}$ Ed. Prentice Hall International Inc. pp 892-893.

Kibuhamusohe, J. W., Davies, D. R. and Hutt, M. S. R. (1974). Membranous nephropathy due to skin lightening cream. $\mathrm{Br}$ Med $J$ 2: 646647. 
Kuhnert, P. M. Kuhnert, B. R. and Ehrard, P. (1981). Comparison of mercury levels in maternal blood, fetal cord blood and placental tissues. Am J Obstet Gynecol 139: 209213.

Lauwerys, R. Bonnier, C. H., Evrard, P. H., Gennart, P. H. and Bernard, A. (1987). Prenatal and early postnatal intoxication by inorganic mercury resulting from the maternal use of mercury containing soap. Hum Toxicol 6: 253-256

Lyons, T. J., Christu, C. N. and Larsen, F. S. (1975). Ammoniated mercury ointment and the nephrotic syndrome. Minn Med 58: 383 384.

Marzulli, F. N. and Brown, D. W. C. (1972). Potential systemic hazards of topically applied mercurials. J Soc Cosmet Chem 23: 875-886

Millar, A. (1916). Perchloride of mercury poisoning by absorption from the vagina. $\mathrm{Br} \mathrm{Med} \mathrm{J}$ 2: 453-454.

Neubert, D., Stahlman, R. Chahoud, I. and Bochert, G. (1985). Some aspects of prenatal toxicology. Trends in Pharmacological Sciences (T.I.P.S.) FEST suppl. 21-26.
Rosenman, K. D., Valciukas, J. A., Glickman, L., Meyers, B. R. and Cinotti, A. (1986). Sensitive indicators of inorganic mercury toxicity. Arch Environ Health 41: 208-215.

Silverberg, D. S., McCall, J. T. and Hunt, J. C. (1967). Nephrotic syndrome with the use of ammoniated mercury. Arch Int Med 120: 581586.

Turk, J. L. and Baker, H. (1968). Nephrotic syndrome due to ammoniated mercury. $\mathrm{Br} J$ Dermatol 80: 623-624.

U.S. Food and Drug Administration (US FDA) (1992). FDA'S Cosmetics Handbook. Washington, DC: U. S. Department of Health and Human Services, Public Health Service. Food and Drug Administration.

WHO (1991). Environmental Health Criteria 118. Inorganic Mercury, World Health Organisation, Geneva. 